\title{
A role for thyroid hormones in the regulation of diet-induced thermogenesis in birds
}

\author{
BY JEAN-FRANÇOIS GABARROU ${ }^{1 *}$, CLAUDE DUCHAMP ${ }^{2}$, JOHN WILLIAMS ${ }^{1}$ \\ AND PIERRE-ANDRÉ GÉRAERT ${ }^{1}$ \\ ${ }^{1}$ INRA, Station de Recherches Avicoles, 37380 Nouzilly, France \\ ${ }^{2}$ UMR 5578 CNRS-Université, Cl. Bernard Lyon I/LA INRA, 69622 Villeurbane cedex, France
}

(Received 3 September 1996 - Revised 9 April 1997 - Accepted 16 April 1997)

\begin{abstract}
The possible involvement of thyroid hormones in avian diet-induced thermogenesis (DIT) was investigated in two lines of cockerels divergently selected for high $(R-)$ or low $(R+)$ food efficiency. For a given body weight, $R+$ cockerels exhibited a higher food intake than $R-$ cockerels $(+49$ to $+76 \%)$ and increased DIT $(+25 \%)$. Plasma thyroxine $\left(T_{4}\right)$ levels did not differ between lines whatever the feeding status of the birds. Plasma 3,5,3'-triiodothyronine $\left(T_{3}\right)$ level was lower in fasted $\mathbf{R}+$ than in fasted $\mathbf{R}-$ cockerels while the opposite was observed after a meal. Iopanic acid injections reduced both plasma $T_{3}$ concentrations and heat production to the same levels in both lines. Hepatic $5^{\prime}$-deiodinase activity measured with an exogenous sulfhydryl group (dithiothreitol) did not differ between lines, but when the sulfhydryl group was omitted, the activity was higher in $\mathbf{R}+$ than in $\mathbf{R}-$ birds $\left(90 \mathrm{v} .42 \mathrm{pmol} \mathbf{T}_{3} / \mathrm{min}\right.$ per liver). $\mathbf{T}_{3}$-binding capacity of isolated hepatic nuclei was higher $(+76 \%)$ in $R+$ than in $R-$ birds. Long-term or acute pair-feeding of $R+$ cockerels to the level of $R-$ controls did not alter these results. The present results suggest that $T_{3}$, mainly originating from peripheral conversion of $T_{4}$ to $T_{3}$, is involved in DIT in the $R+$ line. Availability of endogenous sulfhydryl groups appears to play an important part in the modulation of hepatic deiodinase activity. The higher concentration of nuclear $T_{3}$ receptors may further increase the effects of the hormone, suggesting a major role of thyroid hormones associated with catecholamines in the stimulation of avian DIT. The underlying thermogenic mechanisms remain to be elucidated.
\end{abstract}

Diet-induced thermogenesis: Thyroid hormones: Birds

In poultry production, two-thirds of the total cost of meat or egg production is expenditure on feed. Hence, the improvement of feed efficiency (the reduction of food intake for a given level of production) has long been a major preoccupation of breeders and geneticists. In laying hens, an important part of the variation in food consumption can be explained by the egg mass, the body weight and its variation (Byerly et al. 1980; Fairfull \& Chambers, 1984). The remaining variation, which is referred to as residual food intake (the ' $R$ ' criterion), may be used in selection for feed efficiency. $R$ is defined as the difference between the individually observed and predicted (by regression between food intake and the egg mass, the body weight and its variation) food intakes. Two experimental lines have been obtained by divergent selection for high $(\mathrm{R}+)$ or low $(\mathrm{R}-)$ residual food intake (Bordas \& Mérat, 1984; Bordas et al. 1992). The observed food intakes differ by $40 \%$ for males of the same body weight and by $30 \%$ for females for the same body weight and level of egg production after fourteen generations of selection. Body composition differs between lines, but surprisingly, $\mathrm{R}+$ birds are leaner than $\mathrm{R}-$ birds (Zein-El-Dein et al. 1985; 
Tixier et al. 1988; El-Kazzi et al. 1995). Using indirect calorimetry, Géraert et al. (1991) and Gabarrou \& Géraert $(1994 a, b)$ demonstrated that the difference in energy intake was explained by enhanced heat production in the $\mathrm{R}+$ compared with the $\mathrm{R}-$ line. While the BMR and activity levels do not differ between these lines, this difference in heat production originates in an enhanced heat increment of food or diet-induced thermogenesis (DIT) whose regulatory component (Gabarrou et al. 1998) is mainly under $\beta$-adrenergic control in the $\mathrm{R}+$ line (Gabarrou \& Gerraert 1994a,b).

In rats, hyperphagia induced by a cafeteria meal is also accompanied by a large increase in metabolic rate due to a regulatory DIT, under $\beta$-adrenergic control, and increased plasma 3,5,3'-triiodothyronine $\left(\mathrm{T}_{3}\right)$ concentration (Rothwell \& Stock, 1979). In human subjects, Danforth et al. (1979) also suggest that overfeeding induces increased plasma $T_{3}$ concentration while plasma thyroxine $\left(T_{4}\right)$ level remains unchanged. The possibility therefore exists that thyroid hormones, mainly $\mathrm{T}_{3}$ are involved in DIT. $\mathrm{T}_{3}$ may originate either from the thyroid gland or from peripheral deiodination of $T_{4}$ to $T_{3}$. At the cellular level, $\mathrm{T}_{3}$ acts mainly via nuclear receptors, whose concentration is important in determining the cellular response (Lazar, 1993).

The present experiment was performed to investigate whether thyroid hormones control the energy balance of $\mathrm{R}+$ and $\mathrm{R}-$ adult cockerels. Plasma $\mathrm{T}_{3}$ and $\mathrm{T}_{4}$ concentrations were determined in both lines, either in the fed state or after a short-term fast. In order to compare $\mathrm{R}+$ and $\mathrm{R}-$ lines for a given energy intake level, one group of $\mathrm{R}+$ birds was restricted for 10 weeks to the energy intake of $\mathrm{R}-$ cockerels. A second group of $\mathrm{R}+$ birds was tube-fed once with the same amount of food as $\mathrm{R}-$ birds. To investigate the control of plasma $T_{3}$ concentration by peripheral deiodinase, the effect of iopanoic acid on energy expenditure and on plasma $\mathrm{T}_{3}$ and $\mathrm{T}_{4}$ concentrations was investigated in vivo and the activity of hepatic $5^{\prime}$-deiodinase was also determined. The concentration of $\mathrm{T}_{3}$ binding sites was also estimated on isolated hepatic nuclei.

\section{MATERIALS AND METHODS}

\section{Animals and diet}

Adult cockerels of the twentieth generation of the $\mathrm{R}+$ and $\mathrm{R}-$ lines (Bordas et al. 1992), aged 36-50 weeks at the time of the experiments, were reared in individual battery cages. They were fed on a standard complete diet containing $12.84 \mathrm{MJ}$ metabolizable energy (ME) and $126 \mathrm{~g}$ crude protein $/ \mathrm{kg}$. Birds had free access to water. Ambient temperature was maintained at $20^{\circ}$ in the thermoneutral zone of the cockerels. The lighting programme was $14 \mathrm{~h}$ light : $10 \mathrm{~h}$ dark.

\section{Expt 1}

To enable comparison of $\mathrm{R}+$ and $\mathrm{R}$ - cockerels for a given level of energy intake, three groups of seven birds were selected from the two populations of $\mathrm{R}+$ and $\mathrm{R}-$ birds. Seven cockerels of each line had free access to food ( $R+F$ and $R-F)$ and food intake was measured daily. Seven $R+$ birds $(R+P)$ were individually selected for the corresponding body weight of an $R-F$ cockerel. They were pair-fed daily with the food intake of the $\mathrm{R}-\mathrm{F}$ cockerel of the same body weight for 10 weeks. Birds were weighed before and after the restriction period. Blood was collected before the restriction period after a $16 \mathrm{~h}$ fast, and after the restriction period when re-fed. Blood was collected via a wing vein using a heparinized syringe. Plasma was separated and stored at $-20^{\circ}$ until determination of $\mathrm{T}_{3}$ and $T_{4}$ by radioimmunoassay as described previously by Gabarrou (1996). At the end of 
the experiment, birds were bled and killed by cervical dislocation $4 \mathrm{~h}$ after the onset of light; thus they had free access to food for $4 \mathrm{~h}$ before death. The liver was dissected rapidly, frozen in liquid $\mathrm{N}_{2}$ and kept at $-70^{\circ}$ until analysis.

5 -Deiodinase activity was determined as described previously in chickens by Kuhn $e t$ al. (1987) with slight modifications. In brief, $1 \mathrm{~g}$ liver was homogenized in four volumes of Tris-sucrose-EDTA buffer ( $0.05 \mathrm{M}$-Tris-HCl, $0.25 \mathrm{M}$-sucrose, $0.005 \mathrm{M}$-EDTA, $\mathrm{pH} 7.2)$ and centrifuged at $10000 \mathrm{~g}$ for $30 \mathrm{~min}$ at $4^{\circ}$. Duplicate $0.2 \mathrm{ml}$ portions of the supernatant fraction were immediately incubated in $0.4 \mathrm{ml}$ Tris-sucrose-EDTA buffer, $0.1 \mathrm{ml} 12.8 \mu \mathrm{M}$ $\mathrm{T}_{4}$ solution with or without $0.1 \mathrm{ml} 20 \mathrm{mM}$-dithiothreitol (DTT). One series of tubes was kept on ice and $2 \mathrm{ml}$ ice-cold $950 \mathrm{ml} / 1$ ethanol and $0.2 \mathrm{ml} \mathrm{8-anilino-naphthalenesulfonic}$ acid (ANS; $1 \mathrm{mg} / \mathrm{ml}$ ) were added. Other tubes were incubated for $30 \mathrm{~min}$ at $37^{\circ}$. The reactions were stopped by cooling the tubes on ice and adding $2 \mathrm{ml}$ ice-cold ethanol and $0.2 \mathrm{ml}$ ANS. The tubes were centrifuged at $3000 \mathrm{~g}$ for $20 \mathrm{~min}$. The supernatant fractions were diluted threefold with buffer and assayed for total $\mathrm{T}_{3}$ using a Coat-a-Count RIA kit (Diagnostics Products Corporation, Los Angeles, CA, USA). Protein concentration of the liver homogenates was determined by the bicinchoninic acid method and ranged between 25 and $30 \mathrm{mg} / \mathrm{ml}$.

\section{Expt 2}

To enable a comparison of $R+$ and $R-$ cockerels for a given level of energy intake, three groups of five birds were selected from the two populations of $\mathbf{R}+$ and $\mathbf{R}-$ birds. Five cockerels of each line were fasted for $16 \mathrm{~h}$ and tube-fed with $50 \%$ of their ad libitum food intake: 67 and $43 \mathrm{~g}$ food for $\mathrm{R}+\mathrm{F}$ and $\mathrm{R}-\mathrm{F}$ groups respectively. Five $\mathrm{R}+$ birds $(\mathrm{R}+\mathrm{P})$ were also fasted for $16 \mathrm{~h}$ but tube-fed with only $43 \mathrm{~g}$ food (as $\mathrm{R}-\mathrm{F}$ group, see Table 1 ).

Birds were weighed after the fast and before tube-feeding. Blood was collected after the fast and $4 \mathrm{~h}$ after tube-feeding. Blood was processed as in Expt 1. Birds were killed as described earlier $4 \mathrm{~h}$ after tube-feeding and the liver was dissected rapidly and frozen as in Expt 1 . Deiodinase activity was determined as described earlier. Liver $\mathbf{T}_{3}$ receptor level was determined as described by Dauncey et al. (1992) with some modifications. Briefly, liver samples were homogenized in buffer A containing: $0.2 \mathrm{mM}-\mathrm{K}_{2} \mathrm{HPO}_{4}, 0.6 \mathrm{mM}$ $\mathrm{KH}_{2} \mathrm{PO}_{4}, 250 \mathrm{mM}$-sucrose and $1 \mathrm{mM}-\mathrm{MgCl}_{2}(\mathrm{pH} \mathrm{6.8})$, with the addition of $1 \mathrm{ml}$ Triton X$100 / 1$. The homogenates were then filtered through a mesh of $35 \mu \mathrm{m}$ pore size. The filtrate was centrifuged at $750 \mathrm{~g}_{\max }$ for $10 \mathrm{~min}$ and the pellet was washed twice in buffer A. The final pellet was layered over buffer B containing: $3.5 \mathrm{mM}-\mathrm{K}_{2} \mathrm{HPO}_{4}, 2.3 \mathrm{M}$-sucrose and $1 \mathrm{mM}-\mathrm{MgCl}_{2}\left(\mathrm{pH} \mathrm{6.8)}\right.$, and centrifuged at $70000 \mathrm{~g}_{\max }$ for $50 \mathrm{~min}$. The pelleted nuclei were washed in buffer $\mathrm{C}$ containing: $0.2 \mathrm{mM}-\mathrm{K}_{2} \mathrm{HPO}_{4}, 0.6 \mathrm{M}-\mathrm{KH}_{2} \mathrm{PO}_{4}, 320 \mathrm{mM}$-sucrose and $1 \mathrm{mM}-\mathrm{MgCl}_{2}$ and $1 \mathrm{mM}-\mathrm{CaCl}_{2}$ (pH 6.8). This appeared to be an essential step to avoid aggregation of nuclei. They were finally suspended in buffer $\mathrm{D}$ containing: $10 \mathrm{mM}$-Tris, $320 \mathrm{mM}$-sucrose, $3.2 \mathrm{mM}-\mathrm{MgCl}_{2}$, and $5 \mathrm{mM}$-DTT ( $\mathrm{pH} \mathrm{7.4)}$ ). All procedures were carried out at $4^{\circ}$.

The DNA content of the nuclear extract was determined by the method of Labarca \& Paigen (1980). Portions $(200 \mu \mathrm{l})$ of the nuclear suspension containing $30 \mu \mathrm{g}$ DNA were incubated in duplicate for $30 \mathrm{~min}$ at $37^{\circ}$ with $100 \mu{ }^{125}$ I-labelled $T_{3}$ (NEN, Life Science Products, Boston, USA) and increasing concentrations of unlabelled $\mathrm{T}_{3}$ in buffer $\mathrm{D}$. Tubes used to measure non-specific binding contained a 100 -fold excess of unlabelled $T_{3}$. The nuclei were then centrifuged at $3500 \mathrm{~g}$ for $10 \mathrm{~min}$. The pellet was washed twice in buffer D containing $10 \mathrm{ml}$ Triton X-100/1 and its radioactivity measured on a gamma counter (Auto gamma 5110, Packard, Warrenville, USA). Sufficient DNA was obtained from 2-3 g liver. 
Liver samples of one cockerel from each group were always analysed within the same nuclear isolation and assay, because of possible variations between assays. Values for specific maximal $T_{3}$ binding capacity $\left(B_{\max }\right)$ and the dissociation constant for specific $T_{3}$ receptors $\left(K_{d}\right)$ were obtained from Scatchard plots of bound/free $v$. bound after correction for non-specific binding.

\section{Expt 3}

Birds of the two lines had free access to food and water. Before the experiment, birds were individually weighed. Food intake was determined daily. Nine cockerels of each line were injected subcutaneously with iopanoic acid $(50 \mathrm{mg} / \mathrm{kg})$ and nine control cockerels of both lines were similarly injected with saline solution $(9 \mathrm{~g} \mathrm{NaCl} / \mathrm{l})$ as described by Decuypere $e t$ al. (1980). Birds received one subcutaneous injection per day in the morning for $2 \mathrm{~d}$. Before the first injection, blood was collected and processed as in Expt 1. During the $4 \mathrm{~h}$ following the second injection birds had free access to food. They were then transferred to individual respiratory chambers to measure their energy balance for $4 \mathrm{~h}$. To reduce activity during heat production measurement, birds had no food, no water and no light. After the $4 \mathrm{~h}$ period of heat production analysis, blood was collected and analysed as in Expt 1. At the same time, rectal and comb temperatures were determined using thermocouples (N93722 and N93713, Bioblock Scientific, France) previously calibrated against a $\mathrm{Hg}$ thermometer. Activity was measured using a Doppler radar system. $\mathrm{O}_{2}$ consumption and $\mathrm{CO}_{2}$ production were measured using an automated indirect multi-calorimetry system (Géraert, 1990). Heat production (HP) was calculated as:

$$
\mathrm{HP}(\mathrm{kJ})=16 \cdot 18 \mathrm{O}_{2} \text { (litres) }+5 \cdot 02 \mathrm{CO}_{2} \text { (litres) (Romijn \& Lokhorst, 1961). }
$$

HP was measured 5 times/min over a 4 h period.

\section{Statistical analysis}

Data were analysed using ANOVA followed by a post hoc test for between-group differences. $P<0.05$ was considered significant.

\section{RESULTS}

\section{Expts 1 and 2}

The results for the residual food consumption for the two lines of cockerels showed clear differences and $\mathrm{R}+$ birds ate much more than predicted by the null hypothesis. For a given body weight, $\mathrm{R}+\mathrm{F}$ cockerels had a higher food intake $(+40 \%)$ than $\mathrm{R}-\mathrm{F}$ cockerels (Table 1). When pair-fed for a long period of time (10 weeks), $R+P$ birds lost weight $(-10 \%)$. Based on the usual food intake $\mathrm{R}+$ and $\mathrm{R}-$ birds (134 and $86 \mathrm{~g} / \mathrm{d}$ respectively), Expt 2 consisted of tube-feeding the cockerels once, with $50 \%$ of this daily intake.

When subjected to a fast, $R+$ birds exhibited a lower plasma $T_{3}$ concentration than $R-$ birds (Table 2). On the other hand, ad libitum-fed $\mathrm{R}+$ birds exhibited a higher plasma $\mathrm{T}_{3}$ concentration than $\mathrm{R}$ - birds. A similar but non-significant trend was observed in tube-fed birds. Plasma $T_{3}$ concentrations of $R+$ cockerels tended to decrease slightly after a long period of food restriction, but were not affected by the quantity of food given acutely by tube-feeding. In ad libitum-fed birds, no difference between lines was observed in plasma $\mathrm{T}_{4}$ concentration. Long-term food restriction did not affect plasma $\mathrm{T}_{4}$ concentration, whereas fasting increased it significantly in both lines. 
Table 1. Expts 1 and 2. Body weight, food intake and residual food consumption (RFC $\dagger$ ) of cockerels divergently selected for high $(R-)$ or low $(R+)$ food efficiency

(Mean values with their standard errors)

\begin{tabular}{|c|c|c|c|c|c|c|c|}
\hline & \multicolumn{2}{|c|}{$\mathrm{R}+\mathrm{F} \ddagger$} & \multicolumn{2}{|c|}{$\mathrm{R}+\mathrm{P} \ddagger$} & \multicolumn{2}{|c|}{$\mathrm{R}-\mathrm{F} \ddagger$} & \multirow[b]{2}{*}{$P$} \\
\hline & Mean & SEM & Mean & SEM & Mean & SEM & \\
\hline \multicolumn{8}{|l|}{ Expt $1(n 7)$} \\
\hline Body wt before restriction $(\mathrm{g})$ & $3333^{\mathrm{a}}$ & 107 & $3414^{\mathrm{a}}$ & 133 & $3412^{a}$ & 124 & NS \\
\hline Body wt after restriction $(\mathrm{g})$ & $3443^{a}$ & 94 & $3070^{b}$ & 114 & $3548^{\mathrm{a}}$ & 126 & $*$ \\
\hline Food intake $(\mathrm{g} / \mathrm{d})$ & $113^{\mathrm{a}}$ & 4 & $76^{\mathrm{b}}$ & 3 & $76^{\mathrm{b}}$ & 3 & $* *$ \\
\hline RFC (g/week) & $149^{a}$ & 28 & $152^{\mathrm{a}}$ & 21 & $-138^{\mathrm{b}}$ & 45 & $* * *$ \\
\hline \multicolumn{8}{|l|}{ Expt $2(n 5)$} \\
\hline Body wt (g) & $3433^{\mathrm{a}}$ & 273 & $3180^{\mathrm{a}}$ & 131 & $3464^{\mathrm{a}}$ & 162 & NS \\
\hline Food intake $(\mathrm{g} / \mathrm{d})$ & $67^{\mathrm{a}}$ & 4 & $43^{b}$ & 3 & $43^{b}$ & 2 & $* * *$ \\
\hline RFC (g/week) & $181^{a}$ & 22 & $175^{\mathrm{a}}$ & 9 & $-227^{b}$ & 42 & $* * *$ \\
\hline
\end{tabular}

${ }^{\mathrm{a}, \mathrm{b}}$ Mean values within a row with unlike superscript letters were significantly different: ${ }^{*} P<0.05,{ }^{* *} P<0.01$, $* * * P<0.001$.

$†$ Difference between observed food consumption (FC) and FC predicted by the regression: $\mathrm{FC}=\mathbf{a} \times$ body weight $+\mathrm{b} \times$ body-weight gain $+\mathrm{c}$.

$\ddagger \mathrm{R}+\mathrm{F}$ and $\mathrm{R}-\mathrm{F}$ were fed with their ad libitum food intake; $\mathrm{R}+\mathrm{P}$ were pair-fed with $\mathrm{R}-\mathrm{F}$.

Hepatic 5'-deiodinase activity was measured in the presence or absence of DTT as an exogenous provider of essential sulfhydryl-groups (Table 3) since the thiol dependence of $5^{\prime}$-deiodinase is well established (Visser et al. 1976). In the presence of DTT, no difference between lines was observed whatever the level of food intake. When no DTT was added, deiodinase activity was reduced but to a lower extent in the $\mathrm{R}+$ than in the $\mathrm{R}-$ line. Long-

Table 2. Expts 1 and 2. Plasma triiodothyronine $\left(T_{3}\right)$ and thyroxine $\left(T_{4}\right)$ levels of cockerels divergently selected for high $(R-)$ or low $(R+)$ food efficiency

(Mean values with their standard errors)

\begin{tabular}{|c|c|c|c|c|c|c|c|}
\hline & \multicolumn{2}{|c|}{$\mathrm{R}+\mathrm{F}^{\dagger}$} & \multicolumn{2}{|c|}{$\mathrm{R}+\mathrm{P} \dagger$} & \multicolumn{2}{|c|}{$\mathrm{R}-\mathrm{F}+$} & \multirow[b]{2}{*}{$P$} \\
\hline & Mean & SEM & Mean & SEM & Mean & SEM & \\
\hline \multicolumn{8}{|c|}{ Plasma $T_{3}$ concentration $(\mathrm{nmol} / \mathrm{l})$} \\
\hline \multicolumn{8}{|c|}{ Expt $1(n 7)$} \\
\hline Fasting & $0.93^{\mathrm{a}}$ & 0.18 & $0.91^{\mathrm{a}}$ & 0.06 & $1.53^{\mathrm{b}}$ & 0.23 & $*$ \\
\hline Voluntarily fed & $2 \cdot 44^{\mathrm{a}}$ & 0.24 & $1.76^{\mathrm{ab}}$ & 0.14 & $1 \cdot 39^{\mathrm{b}}$ & 0.07 & $* *$ \\
\hline \multicolumn{8}{|l|}{ Expt $2(n 5)$} \\
\hline Fasting & $1.04^{\mathrm{a}}$ & 0.07 & $1.06^{\mathrm{a}}$ & 0.14 & $1.68^{\mathrm{b}}$ & $0 \cdot 14$ & $*$ \\
\hline Tube-fed & $2 \cdot 64^{\mathrm{a}}$ & 0.25 & $2 \cdot 62^{\mathrm{a}}$ & $0 \cdot 21$ & $1.94^{\mathrm{b}}$ & $0 \cdot 15$ & $P=0 \cdot 1$ \\
\hline \multicolumn{8}{|c|}{ Plasma $T_{4}$ concentration $(\mathrm{nmol} / \mathrm{h})$} \\
\hline \multicolumn{8}{|l|}{ Expt $1(n 7)$} \\
\hline Fasting & $45 \cdot 2^{a}$ & $2 \cdot 7$ & $55 \cdot 2^{\mathrm{a}}$ & 4.0 & $47 \cdot 1^{\mathrm{a}}$ & $4 \cdot 5$ & NS \\
\hline Voluntarily fed & $26 \cdot 2^{\mathrm{a}}$ & $2 \cdot 0$ & $32 \cdot 0^{\mathrm{a}}$ & $3 \cdot 0$ & $26 \cdot 0^{\mathrm{a}}$ & $2 \cdot 1$ & NS \\
\hline \multicolumn{8}{|l|}{ Expt $2(n 5)$} \\
\hline Fasting & $35 \cdot 9^{\mathrm{a}}$ & $4 \cdot 3$ & $39 \cdot 5^{\mathrm{a}}$ & 6.7 & $31 \cdot 0^{\mathrm{a}}$ & $2 \cdot 4$ & NS \\
\hline Tube-fed & $16 \cdot 5^{a}$ & 3.2 & $19.2^{\mathrm{a}}$ & $3 \cdot 4$ & $17 \cdot 6^{\mathrm{a}}$ & 2.9 & NS \\
\hline
\end{tabular}

${ }^{a, b}$ Mean values within a row not sharing a common superscript letter were significantly different: ${ }^{*} P<0.05$, ${ }^{* *} P<0.01$.

$\dagger \mathrm{R}+\mathrm{F}$ and $\mathrm{R}-\mathrm{F}$ were fed at their ad libitum food intake level; $\mathrm{R}+\mathrm{P}$ were pair-fed with $\mathrm{R}-\mathrm{F}$. 
Table 3. Expts 1 and 2. Hepatic deiiodinase activity, measured in the presence or absence of dithiothreitol (DTT) as an exogenous provider of sulfhydryl groups, in cockerels divergently selected for high $(R-)$ or low $(R+)$ food efficiency

(Mean values with their standard errors)

\begin{tabular}{|c|c|c|c|c|c|c|c|}
\hline & \multicolumn{2}{|c|}{$\mathrm{R}+\mathrm{F}+$} & \multicolumn{2}{|c|}{$\mathrm{R}+\mathrm{P} \boldsymbol{\dagger}$} & \multicolumn{2}{|c|}{$\mathrm{R}-\mathrm{F}^{\dagger}$} & \multirow[b]{2}{*}{$P$} \\
\hline & Mean & SEM & Mean & SEM & Mean & SEM & \\
\hline \multicolumn{8}{|l|}{ With DTT } \\
\hline \multicolumn{8}{|l|}{ Expt $1(n 7)$} \\
\hline pmol $\mathrm{T}_{3} /$ min per g protein & $55 \cdot 1^{2}$ & 7.9 & $61 \cdot 0^{\mathrm{a}}$ & 5.4 & $62 \cdot 2^{\mathrm{a}}$ & $9 \cdot 3$ & NS \\
\hline pmol $\mathrm{T}_{3} / \mathrm{min}$ per liver & $233^{\mathrm{a}}$ & 27 & $237^{\mathrm{a}}$ & 29 & $325^{\mathrm{a}}$ & 42 & NS \\
\hline \multicolumn{8}{|l|}{ Expt $2(n 5)$} \\
\hline pmol $\mathrm{T}_{3} / \mathrm{min}$ per g protein & $62 \cdot 1^{\mathrm{a}}$ & $11 \cdot 6$ & $50 \cdot 8^{\mathrm{a}}$ & $3 \cdot 3$ & $72 \cdot 8^{\mathrm{a}}$ & $11 \cdot 3$ & NS \\
\hline pmol $\mathrm{T}_{3} / \mathrm{min}$ per liver & $414^{\mathrm{a}}$ & 54 & $320^{\mathrm{a}}$ & 55 & $326^{2}$ & 47 & NS \\
\hline \multicolumn{8}{|l|}{ Without DTT } \\
\hline \multicolumn{8}{|l|}{ Expt $1(n 7)$} \\
\hline pmol $T_{3} /$ min per $g$ protein & $20 \cdot 4^{\mathrm{a}}$ & $2 \cdot 5$ & $16 \cdot 7^{\mathrm{a}}$ & 1.7 & $8 \cdot 1^{b}$ & $2 \cdot 2$ & $*$ \\
\hline pmol $\mathrm{T}_{3} / \mathrm{min}$ per liver & $90^{\mathrm{a}}$ & 9 & $71^{\mathrm{a}}$ & 16 & $42^{b}$ & 13 & $*$ \\
\hline \multicolumn{8}{|l|}{ Expt $2(n 5)$} \\
\hline pmol $\mathrm{T}_{3} / \mathrm{min}$ per $\mathrm{g}$ protein & $15 \cdot 6^{\mathrm{a}}$ & 1.9 & $18 \cdot 3^{\mathrm{ab}}$ & $5 \cdot 8$ & $7.6^{\mathrm{b}}$ & 1.5 & $*$ \\
\hline pmol $\mathrm{T}_{3} / \mathrm{min}$ per liver & $110^{\mathrm{a}}$ & 16 & $99^{\mathrm{ab}}$ & 28 & $36^{\mathrm{b}}$ & 7 & $*$ \\
\hline
\end{tabular}

a,b Mean values within a row not sharing a common superscript letter were significantly different: ${ }^{*} P<0.05$. $\dagger \mathrm{R}+\mathrm{F}$ and $\mathrm{R}-\mathrm{F}$ were fed at their ad libitum food intake level; $\mathrm{R}+\mathrm{P}$ were pair-fed with $\mathrm{R}-\mathrm{F}$.

term food restriction did not significantly reduce deiodinase activity but acute restriction coupled with tube-feeding increased the variability in deiodinase activity. When calculated on a by-liver basis, deiodinase activity without DTT was nearly threefold higher in R+ than in the $\mathrm{R}-$ cockerels.

Scatchard analysis of $T_{3}$ binding to isolated hepatic nuclei indicated one population of binding sites. An estimation of $B_{\max }$ per unit weight of DNA for hepatic nuclear $T_{3}$ receptors was determined. $B_{\max }$ values were significantly higher in $R+$ than in the $R-$ cockerels (1.28 (SE 0.31 ) and 1.32 (SE 0.13 ) for $R+F$ and $R+P$ respectively $v .0 .74$ (SE 0.13 ) for $R-F$ ). Acute pair-feeding to the level of $R-$ birds did not alter hepatic $B_{\max }$ values in $\mathrm{R}+$ cockerels. Estimates of the $\mathrm{T}_{3}$ receptor dissociation constant $\left(K_{d}\right)$ were similar in the three groups of cockerels and averaged 3.5 (SE 0.4) nM.

\section{Expt 3}

As in the first series of cockerels used in Expts 1 and 2, R+ birds ate more $(+76 \%)$ than $\mathrm{R}-$ birds for a similar body weight (Table 4). Heat production was higher in the control $\mathrm{R}+$ than in the control $\mathrm{R}-$ cockerels $(+25 \%)$. No differences in physical activity or $\mathrm{RQ}$ were observed between lines. Although rectal temperature did not differ significantly between lines, comb temperature was higher in the $\mathrm{R}+$ than in the $\mathrm{R}-$ line. Iopanoic acid did not significantly affect food intake in either line, but reduced heat production and comb temperature in the $\mathrm{R}+$ line to the levels measured in the $\mathrm{R}-$ line.

As in Expt 1, there was a higher plasma $T_{3}$ concentration in $R+$ than in $R$ - birds, but no differences in plasma $T_{4}$ concentration (Table 5). Iopanoic acid reduced plasma $T_{3}$ concentration in both lines but to a lower extent in $R-$ than in $R+$ cockerels $(-0.87 v$. $-1.49 \mu \mathrm{mol} / \mathrm{l})$. Conversely, iopanoic acid increased plasma $\mathrm{T}_{4}$ concentration in both lines, but to a lower extent in $\mathrm{R}-$ than in $\mathrm{R}+$ cockerels $(+45.8 v .+61.6 \mu \mathrm{mol} / \mathrm{l})$. 


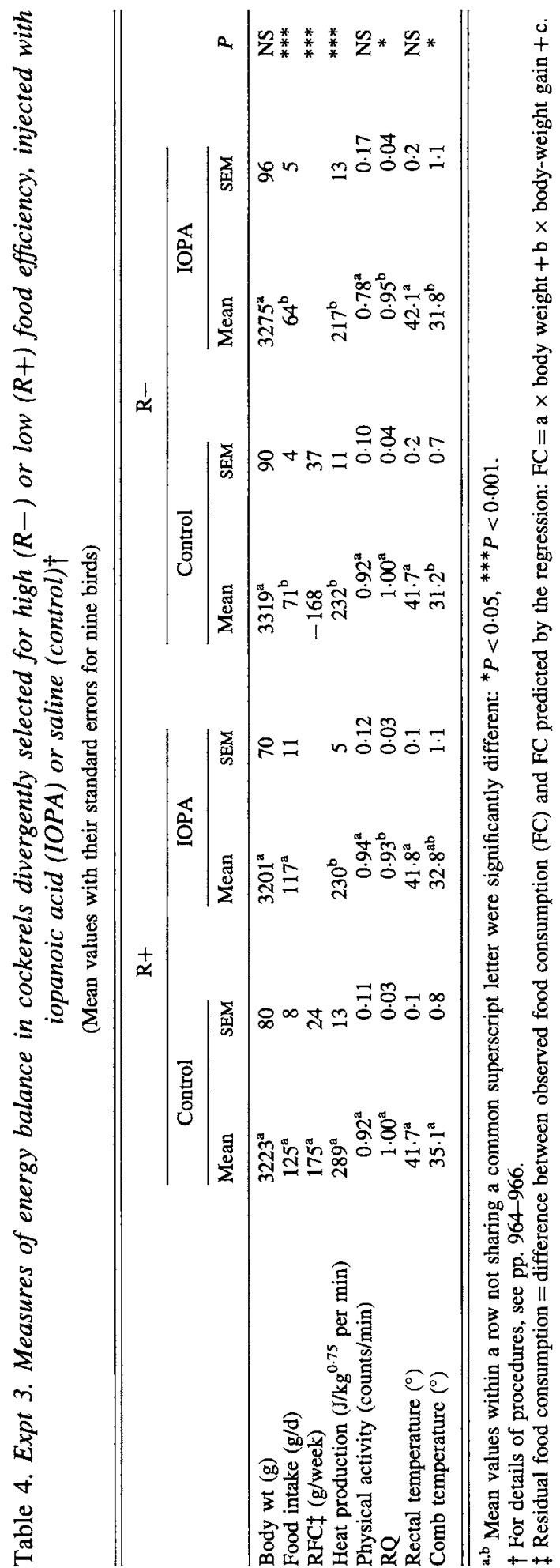


Table 5. Expt 3. Plasma triiodothyronine $\left(T_{3}\right)$ and thyroxine $\left(T_{4}\right)$ concentrations in cockerels divergently selected for high $(R-)$ or low $(R+)$ food efficiency, injected with iopanoic acid (IOPA) or saline (control) $\dagger$

(Mean values with their standard errors for nine birds)

\begin{tabular}{|c|c|c|c|c|c|c|c|c|c|}
\hline & \multicolumn{4}{|c|}{$\mathbf{R +}$} & \multicolumn{4}{|c|}{$\mathbf{R}-$} & \multirow[b]{3}{*}{$P$} \\
\hline & \multicolumn{2}{|c|}{ Control } & \multicolumn{2}{|c|}{ IOPA } & \multicolumn{2}{|c|}{ Control } & \multicolumn{2}{|c|}{ IOPA } & \\
\hline & Mean & SEM & Mean & SEM & Mean & SEM & Mean & SEM & \\
\hline \multicolumn{10}{|c|}{$\begin{array}{l}\text { Plasma } T_{3} \text { concentration } \\
(\mathrm{nmol} / \mathrm{l})\end{array}$} \\
\hline Before injection & $2 \cdot 12^{\mathrm{a}}$ & 0.15 & $2 \cdot 04^{a}$ & $0 \cdot 13$ & $1.73^{b}$ & 0.09 & $1 \cdot 16^{\mathrm{b}}$ & 0.10 & $*$ \\
\hline After & $2 \cdot 11^{\mathrm{a}}$ & 0.11 & $0.56^{\mathrm{c}}$ & 0.07 & $1.70^{b}$ & 0.13 & $0.74^{\mathrm{c}}$ & 0.07 & $*$ \\
\hline$T_{3}$ decrement & $0.01^{\mathrm{c}}$ & $0 \cdot 11$ & $1.49^{a}$ & 0.09 & $0.03^{\mathrm{c}}$ & 0.18 & $0.87^{b}$ & 0.07 & $* *$ \\
\hline \multicolumn{10}{|c|}{$\begin{array}{l}\text { Plasma } \mathrm{T}_{4} \text { concentration } \\
(\mathrm{nmol} / \mathrm{l})\end{array}$} \\
\hline Before injection & $23 \cdot 7^{\mathrm{a}}$ & $2 \cdot 4$ & $24 \cdot 2^{\mathrm{a}}$ & $2 \cdot 0$ & $26 \cdot 2^{a}$ & $1 \cdot 1$ & $26 \cdot 2^{\mathrm{a}}$ & 1.8 & NS \\
\hline After & $25 \cdot 2^{c}$ & $1 \cdot 1$ & $85 \cdot 8^{\mathrm{a}}$ & $5 \cdot 9$ & $28 \cdot 6^{\mathrm{c}}$ & 1.8 & $72 \cdot 0^{\mathrm{b}}$ & 4.6 & $*$ \\
\hline $\mathrm{T}_{4}$ increment & $1.6^{\mathrm{c}}$ & 2.5 & $61.6^{\mathrm{a}}$ & 5.8 & $2 \cdot 4^{\mathrm{c}}$ & 1.8 & $45 \cdot 8^{\mathrm{b}}$ & $4 \cdot 2$ & $*$ \\
\hline
\end{tabular}

a,b,c Mean values within a row not sharing a common superscript letter were significantly different: ${ }^{*} P<0.05$, ${ }^{* *} P<0.01$.

$\dagger$ For details of procedures, see pp. 964-966.

\section{DISCUSSION}

As reported previously (Géraert et al. 1991), $\mathrm{R}+$ birds had a significantly higher food intake than $\mathrm{R}-$ birds (range: +49 to $+76 \%$ ). This could be partly explained by a higher plasma $T_{3}$ concentration in the $R+$ line (May, 1989) and the very low level of fatness observed in this line (Decuypere et al. 1987). The excessive energy intake was balanced by increased heat production $(+25 \%)$ due to increased DIT (Géraert et al. 1991). This enhanced DIT has a regulatory component in the $\mathrm{R}+$ line (Gabarrou et al. 1998) which is under $\beta$-adrenergic control (Gabarrou \& Géraert, 1994a,b).

When birds were fed, plasma $T_{3}$ concentration and heat production were higher in the $\mathrm{R}+$ than in the $\mathrm{R}-$ line, while no difference in plasma $\mathrm{T}_{4}$ concentration was observed between lines. These results are very similar to those observed previously in overfed human subjects (Danforth et al. 1979). When the peripheral conversion of $T_{4}$ to $T_{3}$ was blocked by iopanoic acid, the differences in $\mathrm{T}_{3}$ concentration and heat production disappeared, suggesting that the higher heat production of $\mathrm{R}+$ cockerels was related to the higher plasma $T_{3}$ concentration. There is ample evidence that thyroid hormone administration increases heat production in mammals (Danforth et al. 1979) and birds (Singh et al. 1968; Arieli \& Berman, 1979; Kittok et al. 1982; Hwang-Bo et al. 1990). Futher increases in $\mathrm{T}_{3}$ levels induced by environmental and nutritional changes are associated with an increased resting heat production (Klandorf et al. 1981). The present results also suggest a similar relationship between heat production and thyroid hormone levels in fed animals. In the fasting state or after iopanoic acid treatment, however, the large decreases in plasma $T_{3}$ were not accompanied by significant reductions in resting metabolic rate (Table 4; Géraert et al. 1991; Gabarrou et al. 1998). The marked changes in $\mathrm{T}_{4}$ occurring at the same time may possibly account for part of the difference because $\mathrm{T}_{4}$ can account for 10-15\% of thyroidal effects (Surks \& Oppenheimer, 1977). Alternatively, $\mathrm{T}_{3}$ may act mainly on regulatory mechanisms producing DIT. Because the difference in 
heat production observed between lines has been attributed to DIT (Géraert et al. 1991; Gabarrou et al. 1998), it is tempting to suggest that this mechanism is partly under the control of plasma $T_{3}$ concentration in the $R+$ line.

To investigate the origin of the higher plasma $T_{3}$ concentration observed in the $R+$ line, peripheral deiodination of $\mathrm{T}_{4}$ was blocked in vivo by a short-term treatment with iopanoic acid in both lines (Decuypere et al. 1980). Iopanoic acid caused a greater increase in plasma $\mathrm{T}_{4}$ and decrease in plasma $\mathrm{T}_{3}$ in the $\mathrm{R}+$ than in the $\mathrm{R}-$ line, suggesting a higher rate of secretion of $\mathrm{T}_{4}$ and a higher turnover of $\mathrm{T}_{3}$ in the $\mathrm{R}+$ than in the $\mathrm{R}-$ line. These data strongly suggest that there is a higher conversion of $T_{4}$ to $T_{3}$ in the $R+$ line. When $R+$ cockerels were feed-restricted for a long period of time (Expt 1), $\mathrm{T}_{3}$ concentration decreased slightly, which is consistent with the observation that the level of energy intake influences plasma thyroid hormone levels (Macari et al. 1983). The absence of any effect on plasma $T_{3}$ when feedrestriction was performed acutely by tube-feeding could be the result of the large amount of energy supplied over a short period of time even in 'restricted' $R+$ cockerels.

These results suggest that the higher plasma $T_{3}$ concentration observed in the $R+$ birds could be the result of higher deiodinase activity in this line. When hepatic deiodinase activity was measured with addition of exogenous sulfhydryl-groups, no difference was observed between lines. When hepatic deiodinase activity was measured without addition of exogenous sulfhydryl-groups, $\mathrm{R}+$ cockerels exhibited a higher deiodinase activity than the $\mathrm{R}-$ cockerels. This result suggests that the maximal capacity of deiodination (i.e. availability of enzyme) is similar in both lines and, thus, is not involved in the line-related difference in plasma $T_{3}$ concentration. However, the availability of endogenous sulfhydrylgroups, which markedly affect deiodinase activity (Visser et al. 1976), may limit the activity of the enzyme in vivo. There are indications from earlier studies that the reduced activity of the enzyme observed in starvation was mainly due to a reduction in non-protein sulfhydryl groups (Balsam \& Ingbar, 1979; Harris et al. 1979), although other studies have suggested that the reduced co-factor was only of minor importance (Gavin et al. 1980). From our data, it appears that the lower hepatic deiodinase activity of the $\mathbf{R}-$ line is related to a deficiency of sulfhydryl cofactors in vivo, and not to a reduction in the enzyme concentration. The effect was not related to a difference in energy intake because it was also observed in $\mathrm{R}+$ birds pair-fed to the level of $\mathrm{R}-$ cockerels. In the present study, longterm food restriction did not markedly affect hepatic deiodinase activity contrary to experiments in pigs (Harrison et al. 1996), but the food restriction of adult cockerels was less severe ( $-30 \%$ of ad libitum food intake) than that of young growing pigs $(-50 \%$ of ad libitum intake).

Higher plasma $T_{3}$ levels and hepatic deiodinase activity in $\mathrm{R}+$ cockerels were associated with higher maximum $\mathrm{T}_{3}$-binding capacity of hepatic nuclei indicating a higher concentration of $T_{3}$ receptors. This could be related both to differences in line and to differences in food intake since previous studies have shown $T_{3}$ receptors to be influenced in the long-term by changes in food intake. After 4 weeks of dietary regimens, young pigs provided with a high food intake have a greater number of skeletal muscle nuclear $\mathrm{T}_{3}$ receptors than their counterparts with a low intake (Dauncey et al. 1992). The present findings therefore extend these results to the avian liver. Further, they show that differences in voluntary food intake can also influence tissue concentrations of $T_{3}$ receptors. Acute pair-feeding of $\mathrm{R}+$ cockerels to the level of $\mathrm{R}-$ birds did not reduce the concentration of $\mathrm{T}_{3}$ receptors, possibly because the restriction regimen has rather long-term effects. Because short-term changes in $\mathrm{T}_{3}$ receptors can also take place following a meal (Morovat \& Dauncey, 1992) care was taken so that there was the same time lapse between the time of killing and the last meal in all groups of birds. 
The higher concentration of $\mathrm{T}_{3}$ receptors in $\mathrm{R}+$ cockerels may favour the capacity of thyroid hormones to stimulate heat production in the birds. If such a difference in $T_{3}$ receptors is maintained in the fasted state, it may help to explain the similar resting heat production despite depressed plasma $\mathrm{T}_{3}$ levels.

Avian DIT has previously been shown to be mainly under $\beta$-adrenergic control in the $\mathrm{R}+$ line (Garrabou \& Géraert, 1994a,b). $\mathrm{T}_{3}$ may, therefore, act either directly via an increased number of nuclear receptors and stimulate thermogenesis or by enhancing the sensitivity of tissues to catecholamines (Danforth et al. 1979; Bilezikian \& Loeb, 1983) by modulating the expression of the genes responsible for either the synthesis or translocation to the plasma membrane of $\beta$-adrenergic receptors.

In conclusion, after a meal, $\mathrm{R}+$ cockerels showed a higher heat production associated with higher plasma $T_{3}$ concentration than $R$ - birds. This was related to increased hepatic deiodinase activity dependent on the availability of endogenous sulfhydryl groups. Blocking the rise in $\mathrm{T}_{3}$ with iopanoic acid abolished the rise in heat production. Increased voluntary food intake was associated with increased hepatic $T_{3}$ receptor concentration, further potentiating the effects of thyroid hormones. The enhanced DIT of $\mathrm{R}+$ cockerels, balancing their greater energy intake, is therefore controlled by both catecholamines and thyroid hormones. The biochemical mechanisms of avian DIT now need to be determined.

\section{REFERENCES}

Arieli, A. \& Berman, A. (1979). The effect of thyroxine thermoregulation in the mature domestic fowl (Gallus domesticus). Journal of Thermal Biology 4, 247-249.

Balsam A. \& Ingbar S. H. (1979). Observations on the factors that control the generation of triiodothyronine from thryroxine in rat liver and the nature of the defect induced by fasting. Journal of Clinical Investigation 63, 1145-1156.

Bilezikian, J. P. \& Loeb, J. N. (1983). The influence of hyperthyroidism and hypothyroidism on $\alpha$ and $\beta$ adrenergic receptor systems and adrenergic responsiveness. Endocrine Review 4, 378-388.

Bordas, A. \& Mérat, P. (1984). Correlated responses in a selection experiment on residual feed intake of adult Rhode Island Red cocks and hens. Annales Agriculturae Fenniae 23, 233-237.

Bordas, A., Tixier-Boichard, M. \& Mérat, P. (1992). Direct and correlated responses to divergent selection for residual food intake in Rhode Island Red laying hens. British Poultry Science 33, 741-754.

Byerly, T. C., Kessler, J. W., Gous, R. M. \& Thomas, P. (1980). Feed requirement for egg production. Poultry Science 59, 2500-2507.

Danforth, E. Jr, Horton, E. S., O’Connell, M., Sims, E. A. H., Burger, A. G., Ingbar, S. H., Braverman, L. \& Vagenakis, A. G. (1979). Dietary-induced alterations in thyroid hormone metabolism during overnutrition. Journal of Clinical Investigation 64, 1336-1347.

Dauncey, M. J., Brown, D., Hayashi, M. \& Ingram, D. L. (1992). Thyroid hormone nuclear receptors in skeletal muscle as influenced by environmental temperature and energy intake. Quarterly Journal of Experimental Physiology 73, 183-191.

Decuypere, E., Buyse, J., Scanes, C. G., Huybrechts, L. \& Kühn, E. R. (1987). Effects of hyper- or hypothyroid status on growth, adiposity and levels of growth hormone, somatomedin $\mathrm{C}$ and thyroid metabolism in broiler chickens. Reproduction Nutrition and Development 27, 555-565.

Decuypere, E., Hermans, C., Michels, H., Kühn, E. R. \& Verheyen, J. (1980). Thermoregulatory response and thyroid hormone concentration after cold exposure of young chicks treated with iopanoic acid or saline. In Advances in Physiology Science, vol. 33, Recent Advances of Avian Endocrinology, pp. 291-299 [G. Pethes, P. Péczely and P. Rudas, editors]. Oxford: Pergamon Press Ltd.

El-Kazzi, M., Bordas, A., Gandemer, G. \& Minvielle, F. (1995). Divergent selection for residual food intake in Rhode Island Red egg-laying lines: gross carcase composition, carcase adiposity and lipid contents of tissues. British Poultry Science 36, 719-728.

Fairfull, R. W. \& Chambers, J. R. (1984). Breeding for feed efficiency: poultry. Canadian Journal of Animal Science 64, 513-527.

Gabarrou, J.-F. (1996). La thermogénèse alimentaire chez les oiseaux: composantes, régulations et mécanismes (Diet-induced thermogenesis in birds: components, regulations and mechanisms), pp. 165-167. PhD Thesis, University François Rabelais, Tours, France. 
Gabarrou, J. F. \& Géraert, P. A. (1994a). Regulation of diet-induced thermogenesis. In Proceedings of the 13th Symposium of Energy Metabolism of Farm Animals. European Association for Animal Production Publication no. 76, pp. 113-116. Mojacar, Spain: EAAP.

Gabarrou, J. F. \& Géraert, P. A. (1994b). B-Adrenergic and serotoninergic control of diet-induced thermogenesis in birds. Reproduction Nutrition and Development 34, 634.

Gabarrou, J. F., Géraert, P. A., François, N., Guillaumin, S., Picard, M. \& Bordas, A. (1998). Energy balance of laying hens selected on residual food consumption. British Poultry Science (In the Press).

Gavin, L. A., McMahon, F. A. \& Moeller, M. (1980). Dietary modification of thyroxine deiodination in rat liver is not mediated by hepatic sulfhydryls. Journal of Clinical Investigation 65, 943-946.

Géraert, P. A. (1990). Dépense énergétique et échanges respiratoires: description d'une installation automatisée appliquée aux oiseaux (Thermogenesis and respiratory gas exchanges: description of an automated device for birds). Cahiers de Nutrition et de Diététique 25, 205.

Géraert, P. A., Guillaumin, S., Bordas, A. \& Mérat, P. (1991). Evidence of a genetic control of diet-induced thermogenesis in poultry. In Proceedings of the 12th Symposium of Energy Metabolism of Farm Animals. European Association for Animal Production Publication no. 58, pp. 380-383. Kartause Ittinen, Switzerland: EAAP.

Harris, A. R. C., Fang, S-L., Hinerfeld, L., Braverman, L. E. \& Vagenakis, A. G. (1979). The role of sulfhydryl groups on the impaired hepatic $3^{\prime}, 3,5$-triiodothyronine generation from thyroxine in the hypothyroid, starved, fetal, and neonatal rodent. Journal of Clinical Investigation 63, 516-524.

Harrison, A. P., Rowlerson, A. M. \& Dauncey, M. J. (1996). Selective regulation of myofiber differentiation by energy status during postnatal development. American Journal of Physiology 270, R667-R674.

Hwang-Bo, J., Muramatsu, T. \& Okumura, J. (1990). Effect of dietary protein and fat content on tri-iodothyronineinduced thermogenesis in young chicks (Gallus domesticus). Comparative Biochemistry and Physiology 95A, 429-433.

Kittok, R. J., Greninger, T. J., DeShazer, J. A., Lowary, S. R. \& Mather, F. B. (1982). Metabolic response of the rooster after exogenous thyroid hormones. Poultry Science 61, 1748-1752.

Klandorf, H., Sharp, P. J. \& MacLeod, M. G. (1981). The relation between heat production and concentration of plasma thyroid hormones in the domestic hen. General Comparative Endocrinology 45, 513-520.

Kuhn, E. R., Verheyen, G., Chiasson, R. B., Huts, C., Huybrechts, L., Van den Steen, P. \& Decuypere, E. (1987). Growth hormone stimulates the peripheral conversion of thyroxine into triiodothyronine by increasing the liver 5 -monodeiodinase activity in the fasted and normal fed chicken. Hormone and Metabolic Research 19, 304308.

Labarca, C. \& Paigen, K. (1980). A simple, rapid and sensitive DNA assay procedure. Analytical Biochemistry 102, 344-352.

Lazar, M. A. (1993). Thyroid hormone receptors: multiple forms, multiple possibilities. Endocrine Review 14, 184-193.

Macari, M., Dauncey, M. J., Ramsden, D. B. \& Ingram, D. L. (1983). Thyroid hormone metabolism after acclimatization to a warm or cold temperature under conditions of high or low energy intake. Quarterly Journal of Experimental Physiology 68, 709-718.

May, J. D. (1989). The role of the thyroid in avian species. Critical Review of Poultry Biology 2, 171-186.

Morovat, A. \& Dauncey, M. J. (1992). Short-term changes in the 3,5,3'-tri-iodothyronine nuclear receptor-binding capacity of porcine skeletal muscle following food intake. Journal of Endocrinology 134, 67-72.

Romijn, C. \& Lokhorst, W. (1961). Some aspect of energy metabolism in birds. In Proceedings of the 2nd Symposium on Energy Metabolism of Farm Animals. European Association for Animal Production Publication no. 10, pp. 49-59. Wageningen: EAAP.

Rothwell, N. J. \& Stock, M. J. (1979). A role for brown adipose tissue in diet-induced thermogenesis. Nature 281 , 31-35.

Singh, A., Reineke, E. P. \& Ringer, R. K.. (1968). Influence of thyroid status of the chick on growth and metabolism, with observations on several parameters of thyroid function. Poultry Science 47, $212-219$.

Surks, M. I. \& Oppenheimer, J. H. (1977). Concentration of L-thyroxine and L-triiodothyronine specifically bound to nuclear receptors in rat liver and kidney. Journal of Clinical Investigation 60, 555-562.

Tixier, M., Bordas, A. \& Mérat, P. (1988). Divergent selection for residual feed intake in laying hens: effect on growth and fatness. In Leanness in Domestic Birds, pp. 129-132 [B. Leclercq \& C. C. Whitehead, editors]. London: Butterworths Ltd.

Visser, T. J., Van Der Does-Tobe, I., Docter, R. \& Hennemann, G. (1976). Kinetics of enzymic reductive deiodination of iodothyronines. Biochemical Journal 157, 479-482.

Zein-El-Dein, A., Bordas, A. \& Mérat, P. (1985). Selection divergente pour la composante résiduelle de la consommation alimentaire des poules pondeuses, effets sur la composition corporelle (Divergent selection on residual food consumption in laying hens, effects on body composition). Archiv für Geflügelkünde 49, 158-160. 